\title{
China as a Responsible Power Amid the COVID-19 Crisis: Perceptions of Partners and Adversaries on Twitter
}

\author{
Maria Papageorgiou ${ }^{1}$ (D) Daniella da Silva Nogueira de Meloª $^{\text {(D) }}$
}

Received: 11 February 2021 / Accepted: 20 January 2022 / Published online: 25 February 2022

(c) Fudan University 2022

\begin{abstract}
The challenging COVID-19 context has questioned China's role as a responsible power but also tested its relationship with other states. This study seeks to investigate 'How other actors have perceived China's role as a responsible power amid the COVID-19 crisis'. To do so, we opt for a qualitative approach examining the official Twitter accounts of seven actors that hold different types of relationships with China, namely Brazil, EU, Japan, Iran, Pakistan, Russia, and the USA. We aim to identify the perceptions of these actors towards China as unfolding from January to June 2020, emphasising the empirical applicability of Twitter's discourse. By adopting the concept of responsible power approached from a Role Theory perspective, this paper contributes to a more nuanced understanding of interstate relations and role perceptions. Our findings indicate that there have been variations in the responses and perceptions other states have expressed towards China while its framing as a responsible power differs significantly during the crisis and its landmark events.
\end{abstract}

Keywords China $\cdot$ COVID-19 $\cdot$ Twitter $\cdot$ Role theory $\cdot$ Responsible power

\section{Introduction}

The SARS-CoV-2 was first documented in China in late December 2019, leading to an outbreak of the COVID-19 disease outside of China's borders in the months to follow. As the number of fatalities surged, political leaders started questioning

Maria Papageorgiou

maria_marypapageorgiou@hotmail.com

Daniella da Silva Nogueira de Melo

dani_melo192@hotmail.com

1 Department of Political Science and International Relations, University of Minho, Braga, Portugal

2 Department of Political Science and International Relations, University of Minho, Braga, Portugal 
China's role as a responsible power prompting criticisms both from its closest partners and adversaries. The USA has been highly critical towards China, with President Trump repeatedly referring to the coronavirus as the Chinese Virus.

Despite the criticisms, China has devoted impressive amounts of humanitarian assistance worldwide ( 89 countries and 4 international organisations) ${ }^{1}$ under its socalled mask diplomacy ${ }^{2}$ (Wong 2020), with the provided assistance highly promoted by Chinese media. ${ }^{3}$ In addition, Beijing has sought to extend its soft power (Dworkin 2020), boost its image as a global leader (Verma 2020) and multilateralism supporter. These norms account for considerations that the country acts as a responsible power, a term used widely by the Chinese government and foreign ministry to show the country's commitment to safeguard peace and promote development around the world (XinhuaNet 2019).

The concept of responsible power has been associated with great powers and rising powers in the post-Cold War era on whether they act with greater responsibility (Narlikar 2011). This study outlines China's perceptions as a responsible power and seeks to examine how other actors perceived it during the first wave of COVID-19, using intersubjective connotations as defined by role theory (Thies 2009). Only a few works (Abb 2021; Harnisch et al. 2016; He and Walker 2015; Mehmetcik and Belder 2018) have used role theory as a theoretical perspective to understand states' foreign policy, particularly China's. Nonetheless, role theory is an important analytical approach in studying state behaviour that employs the concept of roles, which are understood to be "social positions...that are constituted by ego and alter expectations regarding the purpose of an actor in an organised group" (Harnisch 2011, p. 08).

These roles are generated not only by an actor's subjective perceptions of what its behaviour should be but also by international demands alongside the context in which the role is being played out (Thies 2013; Stryker and Statham 1985). As a result, role theory can explain how a state's role develops and is influenced by the unfolding of a contemporary crisis (Mehmetcik and Belder 2018). Since the theory holds that roles are relational, intersubjective concepts that cannot be sustained unilaterally but need to be recognised and reified by external actors, the USA, Japan, Russia, Brazil, Iran, Pakistan, and the European Union were selected as cases due to their varying levels of bilateral cooperation and interactions with China in general, as well as during the COVID-19 crisis.

Some of them are regarded as China's comprehensive strategic partners (Brazil, EU, Iran, Pakistan, Russia). At the same time, China's relationships with Japan and the USA account for historical antagonism and distrust with the former and an increased economic, military, and political competition with the latter, as depicted

\footnotetext{
1 Twitter account (@globaltimes, 29 March 2020).

2 The term refers to a specific style of soft (cultural, symbolic, and discursive) and sharp power projection (medical delegations, scientific research teams).

3 Twitter account(@globaltimes, 29 March 2020).
} 
in numerous official documents ${ }^{4}$ and statements. ${ }^{5}$ Geography was also a selection criterion in order to include actors from various regions. Lastly, the designation of these actors as great and emerging powers addresses theoretical preconditions that they need to act as responsible powers (Deng 2008; Wu 2010).

The goal of this study is to analyse and interpret these actors' perceptions of China as a responsible power amid the COVID-19 crisis. To do so, we employ systematic framing analysis and qualitative content analysis as analytical techniques (D'Angelo and Kuypers 2010) to discover the valence towards China and the presence of a responsible power frame by examining official statements in Twitter. Valence is an important element in conveying attitudes because it reveals emotion, sentiment, or tone (Kiousis 2004). In this study, valence is understood as the tone of a message or a story related to an issue (Lams 2016).

Our rationale for using Twitter accounts as the unit of analysis stems from the fact that, over the last decade or so, state officials have widely used social media to enhance interstate communication (Duncombe 2017). Twitter, in particular, is regarded as a powerful tool that has altered the way states' officials interact with one another, unravelling perceptions and signalling intentions in foreign policy. Furthermore, its functionality to "rapidly communicate public health information to citizens" (Rufai and Bunce 2020, p. 510) represents a modern diplomatic tool that covers real-time information to be used in times of crisis.

The reviewed period, known as the first wave of the pandemic, runs from January to June 2020 and serves as a representative sample to capture the changing perceptions of the referred actors as the coronavirus crisis unfolded, with states and organisations involved in national, regional, and international crisis management initiatives (Papageorgiou and Melo 2020; Melo and Papageorgiou 2021). Furthermore, each month during the time period under consideration is marked by significant events.

The findings demonstrate that Pakistan followed by Russia have the most positive valence towards China's; however, only Pakistan has the most consistent framing of China as a responsible power. Brazil, Japan, Iran and the EU in this ascending order show a positive valence, but overall, they adopt a more neutral valence in their tweets while the presence of China as a responsible power frame is sporadic. The USA, on the contrary, holds a highly negative valence and has framed the country in an opposing manner, an irresponsible power. These contradictions are indicative of a highly polarised international environment and the influence of important events in the trajectory of the COVID-19 crisis.

\footnotetext{
${ }^{4}$ The Government of Japan. (2021). Cybersecurity Strategy. Retrieved from https://www.nisc.go.jp/eng/ pdf/cs-senryaku2021-en.pdf Accessed on 17 October 2021.

The United States of America. (2017). National Security Strategy. Retrieved from NSS_BookLayout_ FIN_121917.indd (archives.gov) Accessed on 2 October 2021.

${ }^{5}$ For instance, U.S. Secretary of State Anthony Bliken states "the United States relationship with China will be competitive where it should be, collaborative where it can be, adversarial where it must be". NBC. (2021, March 3).China poses 'biggest geopolitical test'. Retrieved from https://www.nbcnews.com/ news/world/china-poses-biggest-geopolitical-test-u-ssays-secretary-state-n1259489 Accessed on 3 June 2021.
} 
The article is organized as follows. The theory that underpins this research is presented first, followed by an examination of the concept of a responsible power, what it entails, and how China has perceived its role as such. The following section provides a detailed description of the research design, including information on the cases selected, method, coding, data, and time period. Finally, the empirical section presents the study's findings, and the discussion and conclusion provide insights on each actor's perceptions of China as a responsible power while also outlining the study's limitations and suggesting avenues for future research.

\section{Role Theory as Theoretical Framework}

The study of Role Theory originated from Holsti's work in the 1970s when he raised the question of states' national role conceptions and their behaviour in foreign policy. Later, authors such as Thies (2009) and Harnisch et al. (2011) established themselves in the subject by strengthening this theoretical approach's foundations and bringing it closer to the field of international relations. Role theory investigates patterns of foreign policy behaviour based on how the actor perceives its position visà-vis outsiders' expectations and reactions (Breuning 2019). This interaction of corresponding self-perceptions and perceptions by others results in specific roles (Thies 2009; He and Walker 2015).

Thies (2009), Harnisch et al. (2011), Wehner and Thies (2014) investigate three types of interconnected and interbehavioural roles. The first refers to the role conception, which is the actor's self-perception of its social position vis-à-vis others in the international system. The construction of this role derives from the beliefs, values, culture, and history internalized by the actor and the disposition of its material capacities. The second one, namely role performance, is related to the real behaviour of an actor's foreign policy, which is conducted by the social functions assumed by its self-perception. Finally, the actor's self-conception is also closely linked to the external perceptions communicated through language and action (Thies 2009; Harnisch et al. 2011). The third type, thus, consists of role expectations shaped by domestic norms and preferences, the political scenario configurations (Mehmetcik and Belder 2018), and the direct observation regarding the performance of any actor in a social position. Those roles are assigned based on a value dimension of the actor's capacity; “other states' expectations are guided in part by assessments of a state's capacity to act" (Breuning 2019, p. 06). This evaluation results from the actor's mobilisation of both material and immaterial resources. Nonetheless, expectations are subject to variation and role conflicts. Certain functions performed by the actor may not receive the same level of recognition from outsiders in terms of its social position (Mehmetcik and Belder 2018).

Along these lines, actors may assume or be assigned diverse social roles in the international system under an environment of socialisation in which actions and language shape their positions, behaviours, and expectations (Harnisch 2011). On the one hand, the convinced self-perception of its own identity enables the actor to reach and assume a conscious and confident role. On the other hand, when receiving role assignments from third parties, the actor can choose to reject, perform or transpose 
this role. By rejecting the role assignment, the actor is bound to interact with society in a limited manner. As an alternative, the actor can perform the assigned social role by changing its meaning according to its interest (Mehmetcik and Belder 2018).

However, taking on a social role involves the effect of convincing (altercasting) others about its position in order to maintain it. Similarly, role assignments necessitate the ability to persuade others to fulfil delegated functions. In other words, altercasting is a process that implies a "conscious manipulation of one's role-taking behaviour to (re)shape the role of another actor, presumably a counter-or commensurate role" (Harnisch 2011, p. 13). This process is vital for China and its aspirations for a peaceful rise, because "in the struggle for existence and power ... what others think about us is as important as what we actually are. The image in the mirror of our fellow's mind ... determines what we are as members of society" (Morgenthau 1963 , p. 73). To that end, role theory serves as an important analytical lens that can further investigate and comprehend the interplay between an actor's image and the role perceptions of other states to establish and promote a role (Harnisch et al. 2011). As a result, the theory provides foundations and conceptual principles for elucidating the diverse perceptions of China's role as responsible power during the COVID-19 pandemic.

\section{China as a Responsible Power Amid the COVID-19 Pandemic}

The notion of responsible power in international relations is rather vague and lacks a single definition. The term refers to relational linkages that can be interpreted as a social role assignment influenced by both the international community's perception and the actor's conception. This implies that each country holds its own view of what responsibility means and what it entails. As explained by Richardson (2011, p.288) "the standards for defining a responsible power are context-specific and in the eye of the beholder". According to Liping (2001), a responsible power should contribute to regional and world peace efforts and participate in formulating international law. As such Great powers, due to their relative resources, assume a caretaker or a managerial role in the international system (Viola 2020).

To be recognized as a responsible power is to be willing to share costs and take responsibility for international stability. In the context of crisis management, the responsible power is open to sharing reliable information, technical documents and specialized personnel, assuming a transparent position and supporting the international community. An actor committed to a responsibility frame thinks and acts globally; see itself connected to the international system (Buus and Olsson 2006).

In the case of China, calls to act as a responsible stakeholder were made in 2005 by the US Deputy Secretary of State, Robert Zoellick. The so-called Zoellick concept represents an effort to integrate China into the contemporary US-formulated international system, but also as a mechanism to counter China as a threat (Hornát 2012). China, for its part, sees itself as a self-proclaimed responsible state with its sense of responsibility derived from its adherence to UN principles (Chan 2011; de Lisle 2010). Furthermore, the country considers it a self-obligation (Noesselt 2014) to play a more proactive role in shaping the system's rules (Peng 2006), redefining 
its role in relation to other major states while also gaining recognition as a legitimate great power, albeit on its own terms (Suzuki 2008).

China's emergence as a rising power has intensified calls for it to become a responsible power, sharing both the responsibilities and costs of global governance. China has sought to play a more responsible role by adhering to international free trade, nuclear non-proliferation, and environmental standards (Bates and Huang 2006), as well as participating in UN peacekeeping missions (Richardson 2011) and providing humanitarian assistance in times of crisis. Chinese officials have frequently emphasised China's role as a responsible power, noting that "China, as a responsible member of the international community, has always been actively involved in international cooperation to deal with the international financial crisis" of 2008 (Chinese Consulate in Kolkata 2009) and during climate change negotiations in Copenhagen Conference in December 2009, whereby "China, being a responsible member of the global community, will contribute its fair share in battling climate change" (Abou 2009). Therefore, by promoting itself as a responsible power, Beijing has sought to alleviate negative perceptions disseminated by outsiders (Noesselt 2014).

The COVID-19 crisis provided an opportunity for China to solidify its status as a great power while also promoting its image as a responsible power. Given its previous experience with communicable diseases, the country has sought to position itself as a responsible power that brought COVID-19 under control and has hurled to help other countries. In addition, China's previous increased participation in global health regimes has aided its embracement of a multilateral approach to health governance (Chan et al. 2010).

The role of China as a responsible great power (负 责任大国) has been particularly promoted by the Chinese media during the COVID-19 crisis (Thomas 2020). It has also been evident in the state's official rhetoric, with President Xi emphasising in his speeches the importance of solidarity and cooperation in defeating a disease that threatens all (Ministry of Foreign Affairs of PRC 2020).

The Chinese Communist Party (CCP), in an attempt to change the negative image spread by foreign media, has supported narratives that China has become a global leader in the fight against COVID-19. As such, Beijing has responded to political accusations with the issue of a detailed timeline that documents when the country has shared information and initiated cooperation with other countries and organisations (XinhuaNet 2020). Furthermore, President Xi emphasised that China's efforts to control the outbreak had given the rest of the world valuable time to formulate their own responses (Reuters 2020). In addition, Chinese Foreign Ministry spokesman, Geng Shuang, countered criticisms by stating that the country has adopted broad measures to fight the virus according to an open, transparent and responsible spirit claiming that "the international community bears witness to and applauds China's efforts and progress" (Embassy of the PRC in Australia 2020). Nonetheless, international cooperation has been one of China's main strategies to consolidate a positive and responsible image by employing soft power mechanisms (Glaser and Murphy 2009).

Since the outbreak, China has maintained close collaboration with the World Health Organization (WHO) and other countries supplying aid and dispatching 
medical teams to countries in Europe, Africa, Latin America and even the USA. At the regional level, China held a number of meetings with ASEAN ${ }^{6}$ the ASEAN + 3 format ${ }^{7}$ and the African Union, ${ }^{8}$ inaugurating efforts to mobilise necessary resources and hailed solidarity. This aid has allowed China to position itself as a responsible global leader amid a global crisis (Myers and Rubin 2020). These initiatives were frequently communicated on the country's social media. Furthermore, the Chinese Foreign Ministry spokesperson (@MFA_China) has tweeted on various instances about the country's efforts to counter the pandemic. As an illustration of China's solidarity with the international community, official Chinese tweets have emphasised how other actors have been appreciative of it, reinforcing China's own conception of its role as a responsible power. For instance, 'ASEAN said it highly valued China's success in preventing \& controlling \#COVID19, \& thanked China for assistance' (@zlj517, April 1, 2020)while also tweeting other countries' supportive stance 'African leaders highly commended the Extraordinary China-Africa Summit on Solidarity against COVID-19 held on June 17, saying it enhanced their confidence in defeating \#COVID19, and China is a real friend to Africa because China offers help when Africa needs the most' (@MFA_China, June 18, 2020) and 'All things considered China in its social media discourse emphasised on its capacity to act by providing assistance and promoting multilateral efforts, showcased its commitment with the international community and more importantly highlighted other actors' perceptions in shaping its role conception as a responsible power (@中国 驻罗使馆Ambasada Chinei, ${ }^{9}$ February 14, 2020). Overall, China's official social media discourse emphasised its ability to act by providing assistance, promoting multilateral efforts, and demonstrating its commitment to the international community, all of which contributed to its own perception of being a responsible power.

Lastly, another critical point on China's efforts to project its image as a responsible power was a comparison with the US administration decisions (Bachulska 2020). Chinese officials have not hesitated in employing a more assertive tone in responding to the US criticisms with tweets that mention: 'It is immoral \& irresponsible to sow discord when we need solidarity. We urge US to focus on \#COVID19 at home' (@zlj517, April 13, 2020). Also, the Chinese officials retaliated, questioning the US role as a responsible power 'Growing doubts over the US government's handling of the \#COVID19, e.g. When did the first infection occur in the US? Is the US government hiding something? Why they opt to blame others? American people and the

\footnotetext{
6 ASEAN. (2020, February 20). Statement of the Special ASEAN-China Foreign Ministers' Meeting on the Coronavirus Disease 2019 (COVID-19). Retrieved from https://asean.org/statement-of-the-speci al-asean-china-foreign-ministers-meeting-on-the-coronavirus-disease-2019-covid-19/ Accessed on 30 September 2021.

7 ASEAN. (2020, April 14). Joint Statement of the Special ASEAN Plus Three Summit on Coronavirus Disease 2019 (COVID-19). Retrieved from https://asean.org/wp-content/uploads/2021/09/Final-JointStatement-of-the-Special-APT-Summit-on-COVID-19.pdf Accessed on 30 September 2021.

${ }^{8}$ Embassy of the PCR in the Federal Republic of Somalia. (2020, June 26). Joint Statement of the Extraordinary China-Africa Summit on Solidarity Against COVID-19. Retrieved from https://www.mfa. gov.cn/ce/ceso//eng/zfgx_1/t1818730.htm. Accessed on 29 September 2021.

9 Official account on Facebook.
} 
international community need an answer from the US government' (@MFA_China, April 27, 2020).

\section{Research Design}

\subsection{Selected Cases}

The purpose of this research is to identify the tone and frame of China as a responsible power in the political discourse of seven international actors. The actors chosen, which are classified as great and major powers, also represent China's distinct types of bilateral relations, with each accounting for different geographical locations and signalling different levels of interaction during the first wave of the COVID-19 crisis.

Since the early 1990s, China has sought to normalize its relations with other states and regional organisations by establishing a broad network of strategic partnerships and improving its diplomatic ties with its traditional adversaries (Papageorgiou and Cardoso 2021). The first strategic partnership China conducted was with Brazil in 1993, focusing on increasing bilateral trade and investments, expectations that were not fulfilled in the early 1990s (Cardoso 2013). From 2000, there was an exponential growth in their bilateral trade, and in 2012, a new phase was initiated as a comprehensive strategic partnership (Xinhua 2012). However, regardless of the economic cooperation between the two states, China has not been portrayed favourably under Jair Bolsonaro, who described China as a predatory economic power in his presidential campaign in 2018. Moreover, despite statements emphasising the two countries' commitment to combating the pandemic, ${ }^{10}$ there was no evidence of cooperation during the first wave of COVID-19. On the contrary, the Brazilian government's anti-China rhetoric and reference to the China virus triggered a diplomatic crisis and indicated rather strained relations (Patrick 2020).

One of China's most comprehensive strategic partners in the post-Cold war era is Russia, with the rapprochement between the two countries dating back to the early 1990s. After establishing the 1996 partnership of strategic coordination, the two countries have continuously strengthened their ties with a series of agreements aimed at settling territorial issues and expanding mutually beneficial cooperation in various areas (Papageorgiou and Vieira 2021b; Malle 2017). During the first wave of COVID-19, Russia adopted a number of restrictive measures such as early border restrictions (Tass 2020), suspension of e-visa issuances to Chinese nationals (van deVen 2020) that were criticized by Chinese officials as discriminatory. ${ }^{11}$ These early measures exemplified Russia's government and society's mistrust of China

\footnotetext{
10 Twitter account (@EmbaixadaChina, 29 April,2020).

11 Novayagazeta. (2020, February 25). Посольство Китая попросило прекратить проверки китайских граждан в общественном транспорте Москвы (ДОКУМЕНТ). Retrieved from https:// novayagazeta.ru/news/2020/02/25/159339-posolstvo-kitaya-poprosilo-prekratit-proverki-kitayskih-grazh dan-v-obschestvennom-transporte-moskvy
} 
(Gabuev 2020). Despite these measures and initial tensions, Russian officials praised their Chinese counterparts and their response to the COVID-19 while attempting to overcome these challenges, as evidenced by the frequent communication between Presidents Putin and Xi (Weitz 2020). Both states also assisted one another with medical aid (van deVen 2020).

China's diplomatic relations with Pakistan have been cordial for over six decades, and their partnership is described as an All-Weather Strategic Cooperative Partnership, while Pakistan is also considered an important partner in the Belt and Road Initiative (BRI). Their bilateral cooperation has evolved in many spheres (Hameed 2017); however, their relationship is unequal, with Pakistan dependent on China both economically and militarily (Khursheed et al. 2019). In the wake of the COVID-19 outbreak in China, Pakistan decided not to follow other countries in evacuating their citizens from Wuhan, demonstrating solidarity and complete trust in China's measures for dealing with the coronavirus while also donating aid (ChinaDaily 2020). In addition, Pakistan's National Assembly praised China's efforts against COVID-19, ${ }^{12}$ and an even stronger message of amity and cooperation was delivered during Pakistani President Arif Alvi's visit to China in March 2020, ${ }^{13}$ which came at a critical time for China in its fight against the coronavirus (Boni and Adeney 2020). Nonetheless, China repaid this kindness by sending medical and research teams to Pakistan. This reciprocity was highly published on social media by the Chinese newspapers (Zhang 2020).

The Sino-Iranian relationship is based on pragmatic cooperation in areas of mutual interest, with China serving as a prominent political and trade partner for Iran, primarily in the aftermath of the USA's harsh diplomatic and economic sanctions; similarly, Iran has become a critical partner to China's regional energy security strategy (Garver 2016). The pandemic has further isolated Iran, opening space for greater dependence on Beijing (Lim 2020). Amid the COVID-19 crisis, Iran was the first country to receive medical teams from China, while Beijing also advocated for the suspension of sanctions that made it challenging to import medicines and medical equipment. Iranian ambassador Mohammad Keshavarz Zadeh emphasised the Chinese transparency in providing COVID-19 information, statistics and recommendations that have benefited the Iranian government in alleviating the effects of the crisis (Wenting 2020).

China and the EU's strategic partnership was established in 2003, denoting an important relationship with economics at its heart (Freeman 2021). Nonetheless, the two differ in their perceptions of norms, values and modes of international engagement (Geeraerts 2019). As pointed out by Saarela (2018, p. 06), "the EU expects China to assume responsibilities in line with its global impact and to support the rules-based international order". Nonetheless, tensions in their relationship led to

\footnotetext{
12 Radio Pakistan, (2020, February 13). NA passes resolution expressing solidarity with China in their efforts against Coronavirus. Retrieved from http://www.radio.gov.pk/13-02-2020/govt-launches-zindagiapp-to-aware-youth-against-synthetic-drug-penetration-na-told

${ }^{13}$ China Internet Information Center (2020, March 18). Xi holds talks with Pakistani president to deepen ties amid fight against COVID-19. Retrieved from http://www.china.org.cn/world/2020-03/18/ content_75828896.htm
} 
characterisations of China as an economic competitor and systemic rival in 2019 (Rühlig 2020). During the COVID-19 crisis, trade ties among some EU member states and China were strengthened. The EU provided supplies to China when the country was the epicentre, and China later assisted European members with medical aid. However, the COVID-19 crisis accentuated the country's divergences, with Europeans criticising its unfair trade practices, not providing sustainable measures for climate changes and its disinformation campaign (Birnbaum 2020).

Japan and China's complex relationship is built on historical mistrust, competition, and territorial disputes. However, in the last decade and partially due to their increasing trade interdependence, both sides have attempted to normalize their relationship (Przystup 2013). The coronavirus outbreak in China revealed unexpected support from Japan (Burcu and Wang 2020) and a reciprocal generosity that came as a surprise, given that the Sino-Japanese relationship has been one of the world's most strained ( $\mathrm{Li}$ and McElveen 2020). The country has been among the first countries to hail China's prompt response and provide medical aid, while the Liberal Democratic Party decided to deduct 5000 yen $^{14}$ from its members' March salary donated to support China in countering the pandemic (XinhuaNet 2020). At the same time, however, Japan also enacted a $\$ 2.2$ billion stimulus package to assist Japanese companies who wish to relocate their production out of China.

Lastly, the USA and China have a long history of cooperation, competition and animosity. Nonetheless, under the Trump administration, it has been particularly volatile. Since Trump took office, he declared that the USA would revisit its policies and agreements with China (Zaidi and Saud 2020). That led to a series of assertive statements from both sides and an intensive and costly trade war (Medeiros 2019). Moreover, China's designation as a strategic competitor and a revisionist state in official American documents ${ }^{15}$ indicated a somewhat competitive stance towards China, having many scholars attributing these developments under the spectrum of great power politics and the rising of a bipolar international system (Goldstein 2020). The COVID-19 crisis further strained the already tense relations between the two countries. The American president repeatedly accused China of cover-up and failing to control the spread of the pandemic. Additionally, he adopted a series of measures that included restricting travel from China and imposing limits on Chinese students travelling while also threatening to ban Chinese social media applications (Dissis and Hansler 2020). Both sides have also engaged in a social media narrative confrontation around the COVID-19 pandemic that even signalled a change in Twitter policy by flagging and fact-checking politician tweets, including President Trump's and Chinese government spokespeople (Galbraith 2020).

\footnotetext{
14 Approximately 45 US dollars.

15 The United States of America. (2017). National Security Strategy. Retrieved from NSS_BookLayout_ FIN_121917.indd (archives.gov) Accessed on 2 October 2021 and.

The United States of America. (2020). United States Strategic Approach to the People's Republic of China. Retrieved from https://www.whitehouse.gov/articles/united-states-strategic-approach-to-the-peopl es-republic-of-china/ Accessed on 25 October 2021.
} 


\subsection{Unit of Analysis}

Tweets from the official accounts of these actors are used as the unit for analysis, a tool that can signal intentions by reflecting the frames state officials utilise and how 'they wish to be recognised by others' (Duncombe 2017, p. 562). Besides, Twitter has become a prominent role in covering crises and other events that require efficient and timely communication (Spence et al. 2015).

The Tweets ${ }^{16}$ were collected through the advanced Twitter search function using the keyword 'China' with the co-occurrence of the terms 'coronavirus' or 'COVID19', 'pandemic' and 'virus' and also their respective hashtags \#China, \#COVID-19, \#coronavirus, \#pandemic. The search yielded 203 tweets, out of which 62 were from the USA, 15 from Japan, Pakistan 29, EU 11, Brazil 39, Iran 13, and 34 from Russia. This number represents all the published tweets from the selected accounts. For our analysis, we used the English version of three official political authorities' accounts from each actor. For Iran, we use the official accounts of the Foreign Ministry (@ IRIMFA_EN), the Government (@Iran_GOV), and its embassy in China (@IraninChina). For Brazil, we use the accounts of the Minister of Foreign Affairs, Ernesto Henrique Fraga Araújo(@ernestofaraujo), the Government (@govbr) and the Ministry of Foreign Affairs (@ItamaratyGovBr). For Japan, the accounts of the Prime Minister's office (@JPN_PMO), the Government (@JapanGov) and the Ministry of Foreign Affairs (@MofaJapan_en). For Russia, the Kremlin (@KremlinRussia_E), the Government (@GovernmentRF) and the Ministry of Foreign Affairs (@mfa russia). For Pakistan, the accounts of the Prime Minister's office (@PakPMO), President Arif Alvi (@PresOfPakistan) and the Ministry of Foreign Affairs (@ ForeignOfficePk).

For the USA, the accounts of the Department of State (@StateDept), White House (@WhiteHouse) and President Donald Trump(@ realDonaldTrump). Finally, for the EU, we use the official accounts of the European Commission (@EU_Commission), the European External Action Service (@eu_eeas) and the current President of the Commission, Ursula Von Der Leyen (@ vonderleyen).

\subsection{Methods of Analysis}

This study employs content analysis and framing analysis to investigate the predefined frame's presence, valence, and context. Both serve as analytical techniques that contribute to selecting and organizing information about the perceptions extracted from political authorities on Twitter.

In the study of interstate relations in the digital world, framing analysis assists in unravelling the "degree to which the content that is available reflects either favourably or unfavourably on the country" (Manheim and Albritton 1984, p. 645). Additionally, qualitative content analysis allows for "the systematic classification process of coding and identifying themes or patterns" (Hsieh and Shannon 2005, p. 1277).

\footnotetext{
16 Officials' tweets are the primary sources for this study. Tweets are short messages of 140 to 280 characters that provide up to date bursts of information including images, videos and links to other websites.
} 
We followed deductive reasoning seeking to unravel the responsible frame concept in the online political discourse of the actors under analysis on their references to China. This approach allows us to search for priorly established categories and operationalized frames in the material (De Vreese 2003).

This study firstly attributed the relative valence of the tweets as a reference to the tone or attitude of a news story expressed towards someone else (Baumgartner and Wirth 2012). Valence is generally divided into two or four categories in content analysis (positive, negative, neutral, and ambiguous/mixed) (Kiousis 2004; De Vreese and Boomgaarden 2003).

The valence of tweets (positive, neutral, negative) was categorised based on words and expressions representing support, appreciation, progress, cooperation, and compliment for the positive frames and for the negative suspicion, blame, criticism, condemn, and untrustworthiness. Tweets with no positive or negative words and expressions were categorised as neutral. As such, a positive valence implies that Chinese behaviour has promoted a supportive, cooperative, and interdependent environment in the eyes of the other actors. In comparison, the negative valence implies that Chinese behaviour in the face of the COVID-19 crisis has projected a self-interested and manipulative environment. The neutral valence depicts Chinese behaviour as having little influence on the construction of outsiders' perceptions.

Secondly, we reviewed each tweet ${ }^{17}$ to identify explicitly the presence of China as a responsible power frame as well as its opposing frame of irresponsible power, with the use of certain words and phrases (Entman 1993). The coding for the (ir) responsible power, outlined in Table 1, allows us to identify other actors' expectations of China's role.

\subsection{Period of Analysis}

The period of analysis starts in January and concludes at the end of June 2020. The tweets are divided by month to ensure an even distribution; nevertheless, each month is marked by significant landmark events related to the COVID-19 crisis. As a result, this monthly design is critical for understanding how the context of these events influenced the actors' perceptions under consideration. The first coronavirus incidents were officially documented in China on December 31, 2019. The following month, the country became the epicentre of the epidemic, and the government implemented a series of prevention and control measures (Gong et al. 2020), while the WHO Director-General declared the novel coronavirus outbreak a public health emergency of international concern on January 30, 2020 (WHO 2020a, b).

The first death outside of China was reported on February 2 nd, ${ }^{18}$ while China began experiencing medical supply shortages. Other countries provided medical

\footnotetext{
17 Both authors overviewed an initial subset of the Tweets to establish the coding process and to resolve discrepancies before proceeding with the independent categorisation of the tweets; performed by each author to address the issue of reliability. The authors met intercoder reliability of $(\alpha=0.91)$ by using Krippendorff's alpha.

18 BBC. (2020, February 2). Coronavirus: First death outside China reported in Philippines. Retrieved from https://www.bbc.co.uk/news/world-asia-51345855
} 


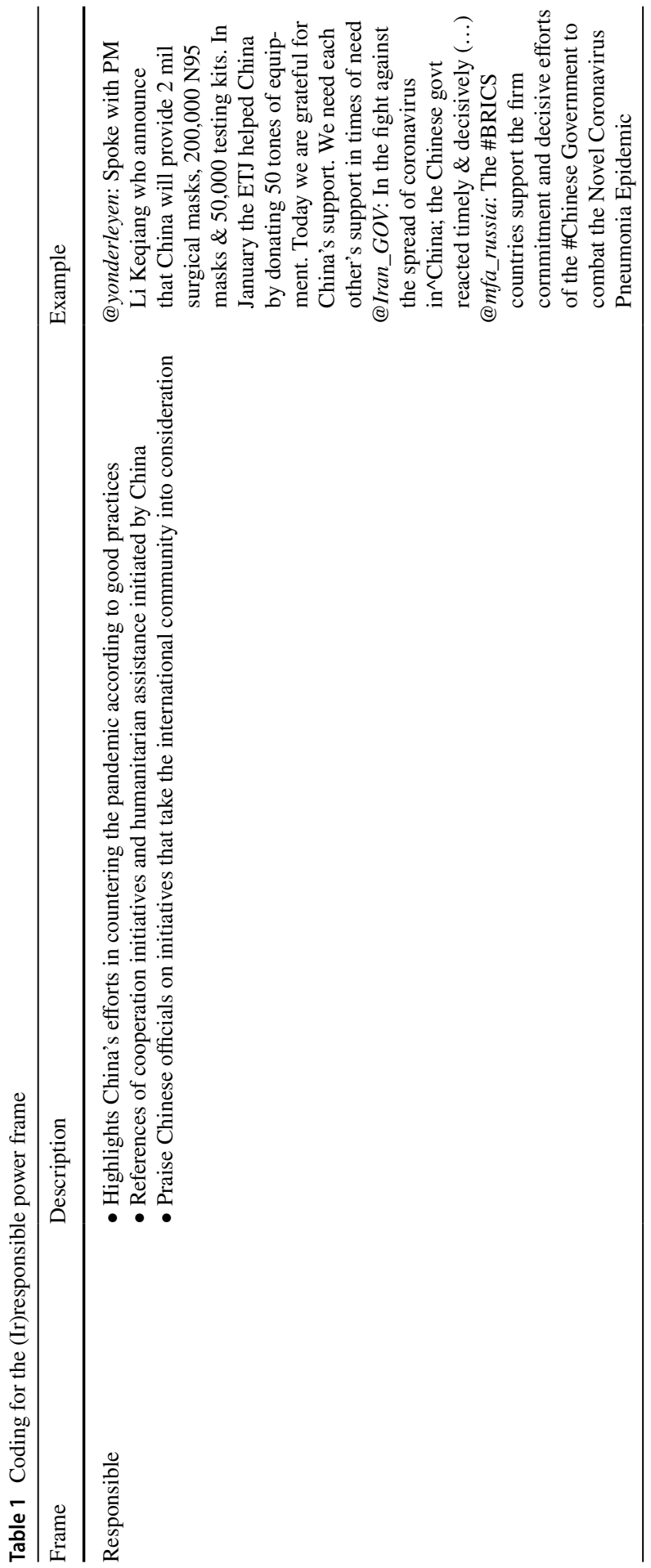




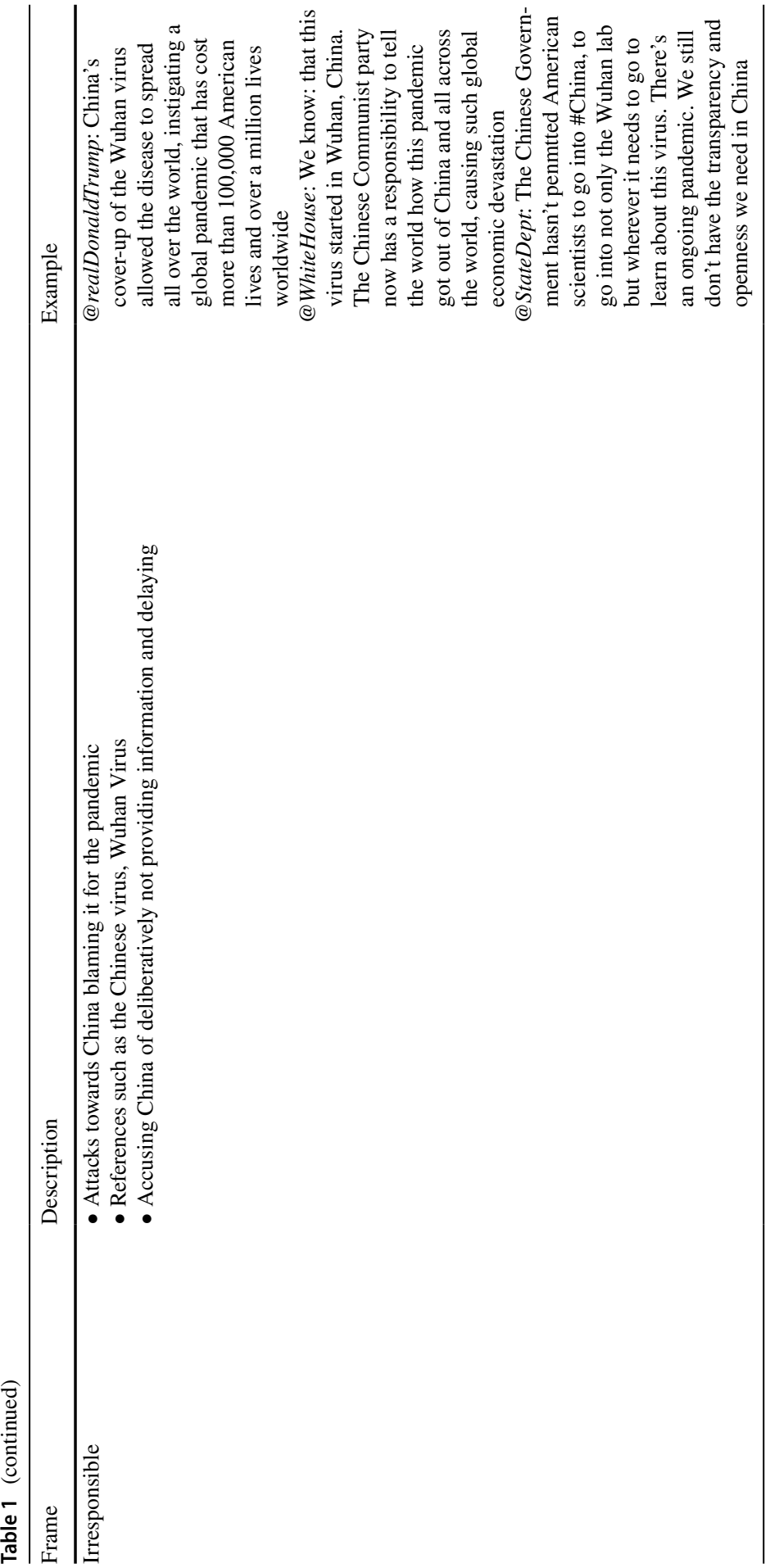


assistance, while also banning flights from China. COVID-19 cases began spreading in many countries in March, with Europe being the epicentre. During this month, the WHO announced that the coronavirus was assigned a pandemic status and several countries declared a National Emergency, banning flights and arranging for the repatriation of their citizens with special charter flights (Cohen et al. 2020).

In April and May, the epicentre shifted from Europe to North America, and by late May, Latin America and Russia were seriously affected. ${ }^{19}$ Several countries began imposing national lockdowns, which had a significantly negative impact on their economic activities. In addition, the spread of coronavirus outside China's borders and its adverse consequences prompted a widespread backlash against China for failing to report its efforts to combat coronavirus in a transparent manner, with many states summoning Chinese ambassadors for explanations (Erlanger 2020). Alongside accusations of disinformation campaigns and fake news spread on COVID-19, an unfavourable international environment towards China was cultivated. ${ }^{20}$

Finally, in May and June, the first announcements of vaccine trials by various states were made, paving the way for a global competition dubbed a global arms race, which exacerbated a nationalist component to a global crisis (Sanger et. al. 2020).

\section{Results}

\subsection{Overall Valence Towards China}

The analysis of the tweets demonstrates the variations in the perceptions of the other actors regarding their attitudes towards China for the entire duration of the analysis (January to June 2020). These perceptions mainly refer to China's performance amid the crisis.

From the findings in Fig. 1, we can see that Pakistan is the country with the most positive valence towards China. The country officials have expressed their support with various tweets such as 'Pakistan stands with the people \& govt of China in their difficult \& trying time, and it will always stand by them. We will be extending every material \& moral support to China just as China has always stood by us

\footnotetext{
19 Read more WHO. (2020a, b, June 29). Listings of WHO's response to COVID-19. Retrieved from https://www.who.int/news/item/29-06-2020-covidtimeline

20 See opinion polls Pew Research Centre. (2020, April 20). U.S. Views of China Increasingly Negative Amid Coronavirus Outbreak. Retrieved from https://www.pewresearch.org/global/2020/04/21/u-s-viewsof-china-increasingly-negative-amid-coronavirus-outbreak/ Assessed on 28 October 2021.

Takshashila Institute. (2020, April). Perceptions of PRC amid Covid-19 pandemic. Retrieved from https://takshashila.org.in/survey-findings-perceptions-of-prc-amid-covid-19-pandemic/ Accessed on 26 October 2021.

Angus Reid Institute. (2020, May, 13). Canadian opinions of China reach new low. Retrieved from https://angusreid.org/covid19-china/ Accessed on 27 October 2021.
} 


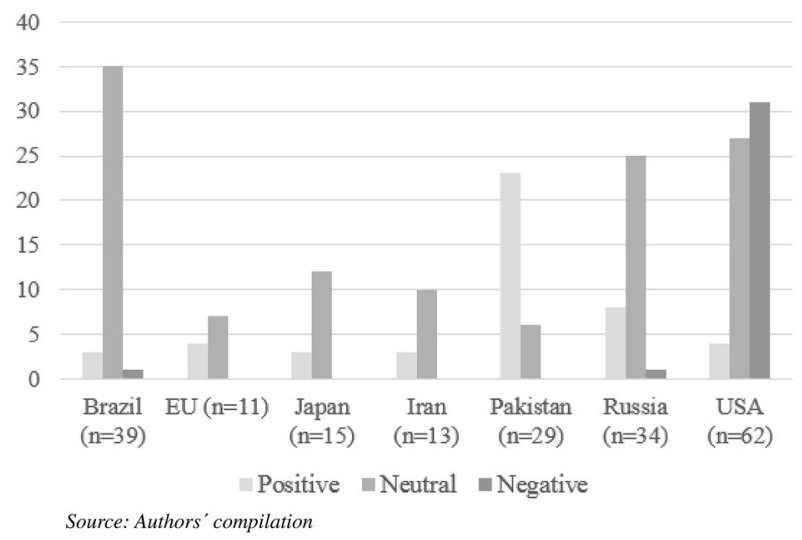

Fig. 1 Overall valence

during all our times of trial and tribulation' (@ImranKhanPTI, February 12, 2020). The rest of the tweets are assigned with a neutral valence, referring to announcements for the situation in China or providing information for the Pakistani citizens in China (@ForeignOfficePk, January 28, 2020).

The results further show that Russia had the second most positive valence towards China but to a far lesser degree than Pakistan, with most of the country's tweets being neutral, mainly referring to agreements and travel instructions in the shared borders of the two countries and phone calls between President's Xi and Putin. Among the tweets with a positive valence, we can add 'Russia's heart is with \#China in this difficult time. \#Russia fully supports the people of China and sincerely wishes them final victory over the epidemic' (@mfa_russia, February 13, 2020). It is also important to note that there has also been one tweet of negative valence towards China in Russia's discourse, stating 'Deputy Prime Minister Tatyana Golikova about \#coronavirus vaccine: Our experts are working on it. As the Chinese side has not provided us with any data on the vaccine and the strain, we are relying on our available sources' (@GovernmentRF, February 3, 2020).

EU, Japan, Brazil and Iran held a neutral valence in their tweets corresponding to telephone conversations, virtual conferences, repatriation of citizens and information for travelling to and from China. Among the four, the EU has the most positive valence. As pointed out by the European Commission, The EU and China have been working together since the beginning of the \#coronavirus outbreak (@EU_Commission, April 8, 2020).

Brazil, among the four, maintained the highest neutral valence towards China's during the examined period. However, it has also a negatively valenced tweet from the Brazilian Foreign Minister responding to the Chinese diplomat Li Yang, 'It is unacceptable that the Ambassador of China endorses or shares offensive posts to the Head of State of Brazil and its voters [...] The Ambassador reaction was disproportionate and damaged good diplomatic practices' (@ernestofaraujo, March 19, 2020). On the other hand, there have also been positively valence tweets, for instance, the Brazilian government's tweet 'The call from President Xi Jinping to 
President Bolsonaro and the excellent dialogue they had, reaffirming the ties of cooperation and trade, shows that, for China, the relationship is as important as for Brazil, and that our foreign policy with China is on the right path' (@ernestofaraujo, March 24, 2020).

Although the neutral tone prevailed in Iranian tweets, there have also been positive in their political statements, such as when the Iranian Foreign Ministry posted '\#Tehran's landmark Azadi tower lit up in solidarity with Chinese people as they fight novel coronavirus. Stay Strong \#China, stay strong \#Wuhan' (@IRIMFA_EN, February 19, 2020).

Japan's neutral valenced tweets highlighted the humanitarian assistance to the country, such as 'The @JapanGov decided to provide emergency relief goods to China through JICA(@jica_direct_en) to respond the request by China, following the novel \#coronavirus Disease Outbreak' (@MofaJapan_en, January 28, 2020).

Lastly, the USA is the one that shows a more negative valence towards China, followed by neutral valence in other tweets. President Trump has often referred to China with highly negative tweets 'All over the World the CoronaVirus, a very bad "gift” from China, marches on. Not good' (@realDonaldTrump, May 28, 2020) and 'As I watch the Pandemic spread its ugly face all across the world, including the tremendous damage it has done to the USA, I become more and more angry at China. People can see it, and I can feel it!' (@ realDonaldTrump, 30 June 2020).

Nevertheless, earlier tweets of him and his government indicate a positive valence towards China 'Just had a long and very good conversation by phone with President $X i$ of China. He is strong, sharp and powerfully focused on leading the counterattack on the Coronavirus. He feels they are doing very well, even building hospitals in a matter of only days' (@ realDonaldTrump, February 7, 2020).

From the overall analysis, we can observe that most actors expressed a neutral valence towards China's performance amid the crisis. Pakistan and the USA constitute the two countries that stand in two opposing terms, with the first being fully supportive and openly acknowledging China's contribution while the latter being highly critical and unsupportive. What comes as a surprise is Russia's neutral valence, given that the country is considered China's closest strategic partner, while Japan's neutral valence signals an attempt not to exacerbate existing geopolitical tensions. Lastly, EU, Brazil, Iran's neutral tone is somewhat expected given that their relationship with China is mainly dependent on economic ties.

\subsection{Monthly Valence}

The monthly data (Fig. 2) indicate that Pakistan, EU and Russia have expressed the highest positive valence between February and April. Pakistan adopted a more positive tone towards China in March when the country was heavily criticised for its efforts to counter the pandemic; however, since April, the neutral valence prevails while there is no negative valence identified. For Russia, the positive valence is present in February, which is at the highest, and in March and April, it slightly decreases. In this actor's analysis, there is a negative valence also in February. This can be explained by the earliest tensions in the two states' responses to COVID-19. 
Brazil

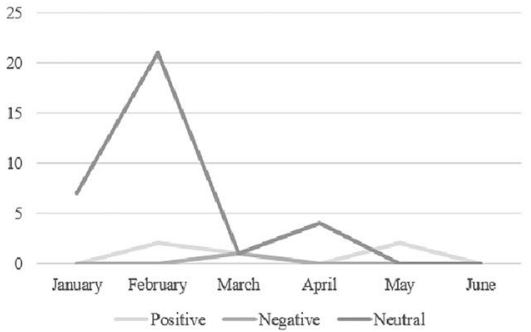

Japan

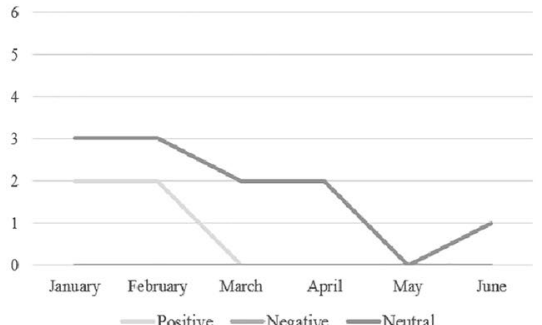

Pakistan

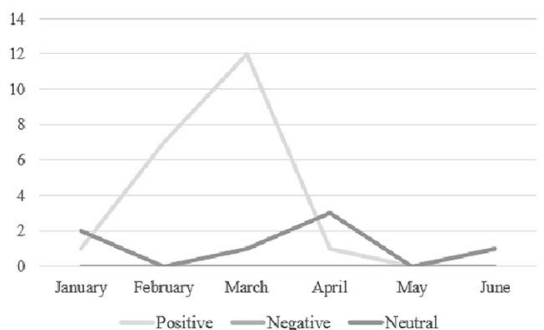

EU

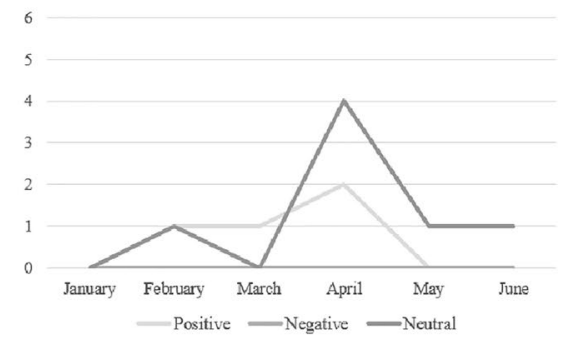

Iran

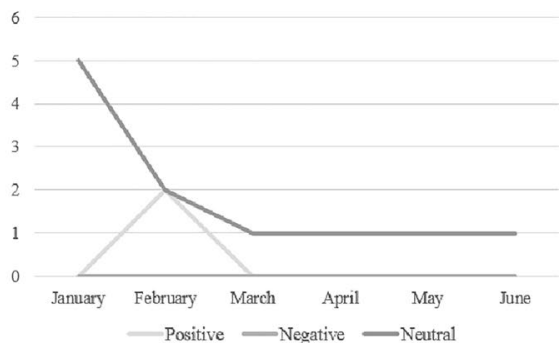

Russia

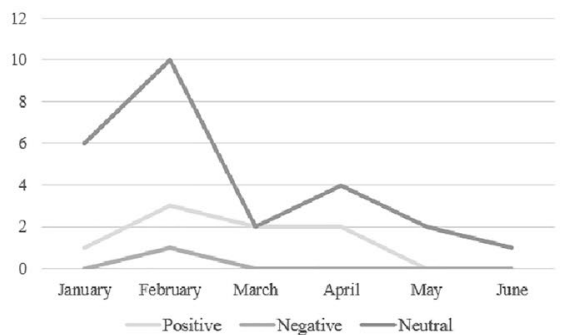

USA

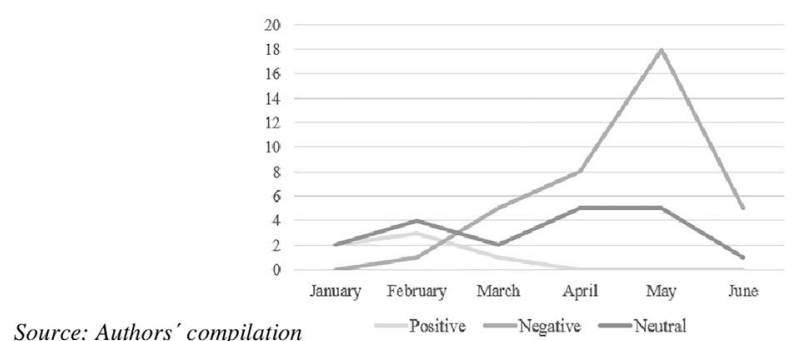

Fig. 2 Actors' valence per month

From March till June, the tone is mainly neutral, while in May and June is significantly increased, with that being attributed to the country's growing infection rates. 


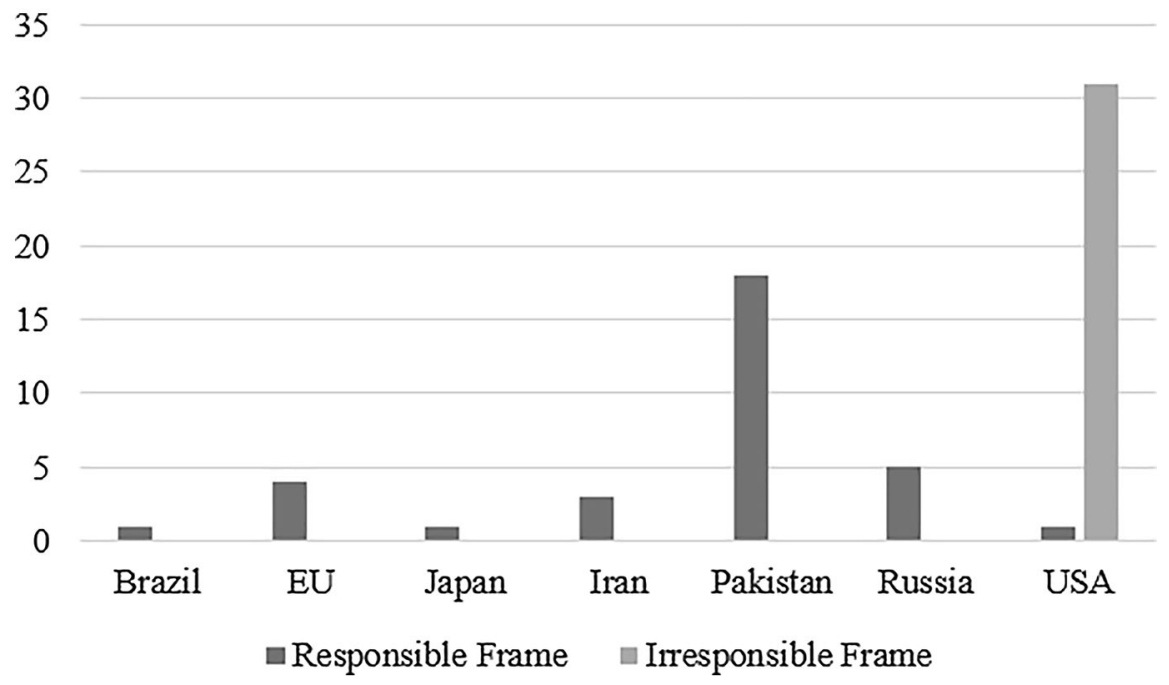

Fig. 3 Overall framing analysis

For Iran, the USA and Japan, the positive valence is more predominant in January and February and is not present after March. Iran's positive valence is mostly present in February, while it holds a steady neutral valence in the remaining months from March to June. Since March, Japan has shown a declining neutral valence, with a significant drop in May. Brazil has two peaks in positive valence, one in February and one in May, while its peak in neutral valence is identified in February and April. On the other hand, the EU has positively valenced tweets in both February and March, with its peak in April being the same also for the neutral valence. In May and June, its neutral valence is steady. Lastly, after a small number of positive valenced tweets in January and February, the USA started being continuously negatively valenced from February onwards, reaching a peak in May.

The highest positive valence in January and February can be attributed to the fact that COVID-19 was only an internal Chinese issue, and other actors did not consider the broader implications. However, as the disease spreads beyond Chinese borders, we see a decrease in the number of tweets with a positive valence from all actors. In comparison, after the declaration of COVID-19 as a pandemic in March, a more neutral valence developed. In contrast, after April, when the pandemic had spread to many other countries that had to impose national lockdowns and criticisms of China were increasing, the neutral valence also significantly decreased. This indicates resistance in openly acknowledging China's performance in a highly polarised environment that promoted inward national policies, and interregional initiatives were scarce. Nonetheless, most actors lacked a negative tone, except for one tweet from Russia, Brazil and the USA, which maintained a negative tone against China for months. 
Table 2 Total number of (Ir)responsible power frames for each month in 2020 related to COVID-19

\begin{tabular}{|c|c|c|c|c|c|c|c|c|}
\hline \multirow[t]{2}{*}{ Month } & & \multicolumn{7}{|l|}{ Actors } \\
\hline & & Brazil & EU & Japan & Iran & Pakistan & Russia & USA \\
\hline January & $\begin{array}{l}\text { Responsible } \\
\text { Irresponsible }\end{array}$ & & & 1 & 1 & 1 & & 1 \\
\hline February & $\begin{array}{l}\text { Responsible } \\
\text { Irresponsible }\end{array}$ & 1 & & 1 & & 6 & 3 & 1 \\
\hline March & $\begin{array}{l}\text { Responsible } \\
\text { Irresponsible }\end{array}$ & & 1 & & 2 & 9 & & 6 \\
\hline April & $\begin{array}{l}\text { Responsible } \\
\text { Irresponsible }\end{array}$ & & 3 & & & 1 & 2 & 3 \\
\hline May & $\begin{array}{l}\text { Responsible } \\
\text { Irresponsible }\end{array}$ & & & & & & & 17 \\
\hline June & $\begin{array}{l}\text { Responsible } \\
\text { Irresponsible }\end{array}$ & & & & & 1 & & 4 \\
\hline Total & $\begin{array}{l}\text { Responsible } \\
\text { Irresponsible }\end{array}$ & 1 & 4 & 2 & 3 & 18 & 5 & $\begin{array}{r}1 \\
31\end{array}$ \\
\hline
\end{tabular}

\subsection{China's Framing as (Ir)responsible Power}

Figure 3 shows the explicit references of China as a responsible power frame and outlines whether the referred countries have framed China as a responsible power emphasising its efforts to provide timely and transparent information, assist in multilateral initiatives and provide humanitarian aid. It also accounts for the irresponsible power frame with accusations of concealing information, not upholding good international practices and global health standards. The results show that the responsible power frame is not consistently present in most actors. It is observed that Pakistan, in its online political discourse, has the highest number of the responsible power frame (18) followed by Russia (5) and the EU (4) while Iran follows with (3), Japan (2) and Brazil only with 1 . On the contrary, the USA has framed China as an irresponsible power 31 times.

\subsection{Monthly Framing}

Table 2 provides an analytical depiction of China's framing as an (ir)responsible power per month. Based on the findings, we can conclude that the responsible power frame is most prevalent in January and February. On the other hand, we only had Pakistan, the EU, and Russia acknowledging this frame between April and June. Furthermore, in all the months recorded, the USA is the only one to present and portray China as an irresponsible power to a very high degree.

In more detail, Russia has adopted a responsible frame five times, three of which in February and twice in April. Among them, as expressed by the Russian Minister 
of Foreign Affairs on China's responsible role '\#Lavrov:\#Russia is ready to contribute to joint efforts on these and other urgent issues on the global agenda, including the threat of epidemics. I note \#China's open and responsible approach to international cooperation in fighting the spread of the \#coronavirus \#MFA \#Diplomacy' (@mfa_russia, February 17, 2020). The framing of China as a responsible power in February, where the COVID-19 has severely impacted only China, indicates an attempt to defuse tensions between them or discourage doubts of their rapprochement. On the contrary, the presence of two responsible power frames in April in a period when both states have engaged in significant soft power measures through mask diplomacy (Fruscione 2021; Kowalski 2021) mainly in Europe while at the same time being accused of disinformation, and propaganda was used by Russia instead as a means to enhance its own "political legitimacy and authority in the West” (Terry and Makarychev 2021, p. 06).

In Pakistan's twitter discourse, the responsible power frame is evident throughout almost every month with tweets such as 'The Prime Minister underscored that timely, effective and far-reaching measures undertaken by China were being acknowledged globally' (@PakPMO, 20 February 2020). This consistent presence of the frame and the emphasis on its prompt and transparent response were employed to highlight China's global leadership role.

In April, the EU framed China three times as a responsible power and once in March. As highlighted by the European Commission, 'we are grateful that China has returned the sign of solidarity by donating masks and testing kits, which arrived in Rome' (@EU_Commission, April 8, 2020). The EU's framing of China as a responsible power is presented, however, as a counter-response to the EU's own role as a responsible power.

Japan has framed China as a responsible power twice, one in January and one in February 'Asked about Japan's assistance towards China on the novel coronavirus, CCS Suga responded that Japan was aware of the all-out effort by the Chinese authority to suppress the virus, and Japan would not spare any effort in providing necessary assistance' (@JPN_PMO, February 6, 2020). The framing in this period indicates that Japan recognized its adversary's solidarity at a time of global crisis, changing its initial position vis-à-vis China.

Iranian political leaders and institutions framed three times China as a responsible power, indicating once in January and twice in March by stating that 'In the fight against the spread of \#coronavirus in \#China, the Chinese gov't reacted timely and decisively \& the Chinese people united throughout the country \& were confident that China would succeed in preventing, controlling and combating the virus' (@ Iran_GOV, January 23, 2020). Iran's framing indicates the strengthening of the strategic partnership with China and its dependence on Beijing in times of crisis.

Brazil and the USA have only one responsible power frame in total. For Brazil, it is expressed in February with the Brazilian President showing gratitude to the China government for the support provided in the repatriation of Brazilian citizens. "We have been following China's efforts to contain or overcome new coronaviruses. We thank the Chinese government for its assistance in the operation of evacuating our citizens in Wuhan.” (@jairbolsonaro, February 4, 2020). This reinforces the 
country's stance of being critical of China's role while not exaggerating its criticisms to safeguard its economic interests.

For the USA, the only framed tweet of China as responsible power was in January when President Trump mentioned that 'China has been working very hard to contain the Coronavirus. The United States greatly appreciates their efforts and transparency. It will all work out well. In particular, on behalf of the American People, I want to thank President Xi!' (@ realDonaldTrump, January 24, 2020). Nonetheless, after the end of February, the USA has started framing China as an irresponsible power with a dramatic increase of thirty-one references in May. To include some of them 'The Chinese Government hasn't permitted American scientists to go into \#China, to go into not only the Wuhan lab but wherever it needs to go to learn about this virus. There's an ongoing pandemic. We still don't have the transparency and openness we need in China' (@StateDept, April 26, 2020) and in a similar manner 'We will continue to hold China accountable for what they did and what they failed to do during the Coronavirus pandemic, Vice President @Mike_Pence says' (@WhiteHouse, June 7, 2020). The United States' extensive framing of China as an irresponsible power is presented as being in opposition to Western values, but it is also premised on an antagonistic environment for global leadership.

\section{Discussion}

According to Role Theory, an actor's behaviour is also influenced by the expectations of others. Third-party perceptions of an actor's role "shape the practices of this actor", and "it is the recognition by others that shapes role performance" (Bengtsson and Elgström 2011, p. 114) Thus, it is possible to evidence the actors' perception of China's role performance by considering the positive, neutral, or negative valence examined in this study and observing whether the expectations held by other actors mirror the presence of the responsible power frame as a role conception.

Russia is considered one of the most important partners of China. Even though the two countries have generally refrained from openly supporting one another in critical events such as the South China Sea dispute, Caucasus Crisis, and the Ukraine Crisis (Korolev and Portyakov 2018), in the COVID-19 crisis, the analysis shows that there have been positive valenced tweets, but still the dominant tone is neutral. In addition, the framing of China as a responsible power is neither highly visible, constant nor at the level expected from Russia, further confirming considerations on the ambiguity of their relationship (Papageorgiou and Vieira 2021a). This overall stance confirms that the two states relationship is based on win-win cooperation (Bordachev 2016) and dissatisfaction with Western norms, particularly on the roles assigned to them (Wishnick 2017; Lubina 2017). Russia's reluctance to adopt a consistently positive tone and frame China as a responsible power stem from its own difficulties in persuading others to recognize its own status as such for its own attempts to gain recognition from the West during COVID-19. As a result, Moscow's reluctance to recognize Beijing as a responsible power originates from its insecurities that such recognition will place it as a junior partner in the two states relationship. 
On the other hand, the analysis indicated that Pakistan was the country that adopted a more positive tone towards China, especially in March when it was heavily criticized for its efforts to counter the pandemic. Also, in Pakistan's online discourse, we have identified most frequently the frame of China as a responsible power. These results are not surprising given the close relationship between the two countries. China and Pakistan have been highly supportive of one another on various occasions, which was also the case during the COVID-19 crisis. Moreover, as one of the BRI's key strategic countries, Pakistan sees China as a generous donor and benevolent contributor to development (MFAPRC 2020). As a result, Pakistanis interpreted China's efforts to combat COVID-19 as an indication of taking responsibility for international stability.

Despite China having supported Brazil with medical equipment donations estimated at more than $\mathrm{R} \$ 30$ million and holding online conferences on exchanging information in the fight against COVID-19, the Brazilian government has barely publicized Chinese initiatives and support on their social networks (Mello 2020). Brazil's neutral tone on Twitter was adopted not to jeopardize the partnership at a time when the country needs China's medical supplies to secure its economic recovery (Stuenkel 2020). Similarly, there is little evidence of the frame of China as a responsible power in the Brazilian twitter discourse, demonstrating that China failed to shape or influence Brazilians' expectations by asserting its role as a responsible power. Brazil has followed American rhetoric and has been cautious in recognizing China's role as a responsible power because it sees it as a potential dominator (Simões 2020).

Amid the pandemic and sanctions, China has become Iran's leading partner. This reflects the solidarity of the Iranian tweets in the early months and the recognition of China's responsible role in controlling the disease during the first months. Even though Iran has praised China's support in opposing US sanctions, it has not shown an overly positive valence towards China on Twitter nor has promoted the framing of China as a responsible power. Iran and China have divergent positions and ambitions about some international issues, undermining the Iranian perception of China as a responsible power (Calabrese 2020). This role would give China legitimacy to be involved in issues in the Middle East, which Iran seeks to avoid, given their competing interests at play in the region (Hong 2014).

During the COVID-19 outbreak in Europe, China exploited the lack of European internal solidarity to strengthen itself as a responsible actor. The rapid Chinese assistance in European member states was appreciated on the EU tweets as an attempt to preserve the Union's normative and ethical nature amid the delay of providing cohesive internal action. Even so, China's frame as a responsible power is not highly mentioned in European tweets. After April, the neutral attitude towards China refers to the EU's more coordinated internal response to the control of COVID-19 and criticism of China's involvement in disinformation campaigns and identification of failures in Chinese medical supplies (Brattberg and Le Corre 2020). Furthermore, China's assistance and diplomatic approach to the EU during the pandemic was contested and portrayed as a propaganda operation (Walkowicz 2020). Moreover, China's mask diplomacy raised European awareness of its overdependence on Chinese 
industry and production chains and its somewhat fragmented response to the pandemic (Santander and Vlassis 2021) that endangers its own role as perceived by its own members. Thus, China was seen by the EU as a self-interested actor that uses its power of influence through the strategy of mask diplomacy to promote its own interests and not as a responsible power willing to share global costs.

An important finding of this analysis is Japan's positive valence towards China that stipulates attempts to mend relations between the two neighbouring countries. On the other hand, China has managed to a lesser degree to conduct an altercasting process with Japanese expectations even though they perceive themselves as adversaries. In January and February, the Chinese role performance convinced the Japanese to see China as a partner in combating COVID-19 and, therefore, initially recognize China in a responsible power role. However, Japan's latest measures and neutral valence reveal a certain level of hesitation in openly assuming China as a responsible power, given the country's relations with the USA. As a result, the role expectations of China as a responsible power were short-lived as soon as US-China relations became seriously strained from February, with Japan maintaining a delicate balancing act between its reliance on the US for security and its economic relationship with China.

The findings of the USA discourse validate the competitive environment between the two countries. The constant accusations of President Trump directed to China, particularly in the months when the COVID-19 affected the USA the most, reveals that this rhetoric instead targets an internal audience (Santis, 2020). China's role conception is not in line with the expectation of the USA. The American narrative has promoted Western values and beliefs in direct confrontation with China's responses. For the USA, expectations for China are mostly negative during the first wave because it is not in its interest to promote a positive and responsible image of China during global crises, especially since its own role has been called into question by its lack of solidarity and cooperation, as well as its ability to provide global leadership (Yuan 2020).

All in all, China's framing as a responsible power from other actors had proven short-lived, only in the first two months when it was still considered an internal Chinese issue. Since then, both the tone regarding China's performance and its framing as responsible power diverge, indicating an inconsistency between China's strategic partners' rhetoric and actual behaviour in adopting an openly supportive stance in times of crisis. In contrast, its adversaries adopt two different stances, one more constrained and one openly confrontational.

\section{Conclusion}

This article contributes to the field of international relations by highlighting the growing convergence of social media, foreign policy, and interstate relations. We employed role theory to outline China's own role conception as a responsible power, followed by an empirical investigation of other actors' expectations and assessments of China's ability to fulfil this role. 
A series of statements from political authorities on Twitter were extracted for the analysis in order to locate the framing of China as a responsible power as well as the valence of statements in an attempt to understand other actors' perceptions and, as a result, their support for China's performance amidst the COVID-19 crisis.

The data revealed the shifting perceptions of China among other actors as the COVID-19 outbreak unfolded. The analysis indicated variations in the states' overall consideration of China as a responsible power and a monthly context. According to the findings, the majority of the positively valenced tweets from the actors under investigation were posted when COVID-19 was only an internal Chinese issue, and the actors did not consider further implications. However, as the disease spread beyond Chinese borders, there was a decrease in the number of positively valenced tweets, and the frame of responsible power diminished. Even China's closest partners, Russia and Iran, resisted recognising China as a responsible power systematically. From the actors under analysis, only Pakistan acknowledges and frames China as a responsible power, while the USA framed the country in an opposing manner, an irresponsible power. The other actors' prevailing neutral valence towards China's performance suggests that the disparity between their expectations of China's role performance stems from Beijing's policies and the highly politicised and polarised environment that characterised the COVID-19 pandemic.

Additionally, China's efforts to achieve a positive international image and recognition as a responsible power were met with criticisms and hesitancy by other actors; thus, leading to the construction of an assertive narrative that indicates discontent with the international status quo and its role as norm-taker. Thus, despite having adopted the role of a responsible power, its attempts to convince the international community of its performance did not materialise. Lastly, the COVID-19 crisis also exacerbated the growing competition for leadership between China and the USA.

This study has some limitations, including a time period that only covers the initial perceptions towards China and a focus on specific Twitter accounts. Future research could, however, expand on these limitations. Furthermore, by adopting this research's theoretical and analytical approaches, other studies can examine China's performance in other contexts and how other international actors perceive it.

Author contribution Both authors contributed equally on the design and implementation of the research, to the analysis of the results and to the writing of the manuscript.

Funding The authors received no financial support for this research.

Data and Code Availability The data that support the findings of this study are available from the corresponding author upon reasonable request.

\section{Declarations}

Conflict of interest The authors declare that there is no conflict of interest. 


\section{References}

Aaabb, Pascal. 2021. From 'Peaceful Rise' to Peacebuilder? How Evolving Chinese Discourses and Selfperceptions Impact Its Growing Influence in Conflict Societies. Journal of Contemporary China 30(129): 402-416.

Abou, Serge. 2009. Climate change: EU, China have work to do. ChinaDaily. http://www.china.org.cn/ environment/opinions/2009-04/28/content_17686450.htm. Accessed on 10 February 2021.

Baumgartner, Susanne E., and Werner Wirth. 2012. Affective Priming During the Processing of News Articles. Media Psychology 15(1): 1-18.

Bengtsson, Rikard, and Ole Elgström. 2011. Reconsidering the European Union's roles in international relations: Self-conceptions, expectations, and performance. In Role theory in international relations, 113-130. Routledge.

Birnbaum, M. 2020. The Washington Post. EU accuses China of waging a pandemic disinformation campaign. https://www.washingtonpost.com/world/eu-accuses-china-of-waging-pandemic-disinforma tion-campaign/2020/06/10/55af8a78-ab1f-11ea-a43b-be9f6494a87d_story.html Accessed on 25 January 2021.

Boni, Filippo, and Katharine Adeney. 2020. The Impact of the China-Pakistan Economic Corridor on Pakistan's Federal System: The Politics of the CPEC. Asian Survey 60(3): 441-465.

Bordachev, Timofei. 2016. Russia and China in Central Asia: The Win-Win Game. Valdai Club. https:// eng.globalaffairs.ru/articles/russia-and-china-in-central-asia-the-great-win-wingame.

Brattberg, Erik, and Philippe Le Corre. 2020. "No, COVID-19 isn't turning Europe pro-China (yet)". The Diplomat. https://thediplomat.com/2020/04/no-covid-19-isnt-turning-europe-pro-chinayet/. Assessed on 6 January 2021.

Brazil-China diplomatic spat escalates over coronavirus supplies I Reuters By Eduardo Simões APRIL 6. 2020. https://www.reuters.com/article/health-coronavirus-brazil-idINKBN21O23Y.

Breuning, Marijke. 2019. Role Theory in Politics and International Relations. In The Oxford Handbook of Behavioral Political Science, ed. Alex Mintz and Lesley Terris, 1-23. Oxford University Press.

Burcu, Oana, and Weixiang Wang. 2020. Land Apart, Shared Sky: Sino-Japanese Relations Amid the COVID-19 Pandemic. China Brief 20(9): 13-17.

Buus, Stephanie, and Eva-Karin. Olsson. 2006. The SARS Crisis: Was Anybody Responsible? Journal of Contingencies and Crisis Management 14(2): 71-81.

Calabrese, John. 2020. China-Iran Relations: The Not-So-Special "Special Relationship." China Brief 20(5): 22-27.

Cardoso, Daniel. 2013. China-Brazil: A Strategic Partnership in an Evolving World Order. East Asia 30(1): 35-51.

Chan, Lai-Ha., ed. 2011. China Engages Global Health Governance: Responsible Stakeholder or System-Transformer? Berlin: Palgrave Macmillan.

Chan, Lai-Ha., Lucy Chen, and Xu. Jin. 2010. China's Engagement with Global Health Diplomacy: Was SARS a Watershed? PLoS Medicine 7(4): 1-6.

ChinaDaily. 2020. Pakistan donates surgical masks to China. http://www.chinadaily.com.cn/a/202002/ 10/WS5e410f7fa3101282172765de.html. Accessed on 1 February 2021.

Chinese Consulate in Kolkata. 2009. President $\mathrm{Hu}$ Jintao Accepts an Interview concerning His Attendance of the Second G-20 Leaders' Summit on Financial Markets and the World Economy. https://www.mfa.gov.cn/ce/cgkolkata//eng/zgbd/t555474.htm.

Cohen Zachary, Marquardt Alex and Atwood Kylie. CNN. 2020. Blame game escalates between US and China over coronavirus disinformation. https://edition.cnn.com/2020/03/24/politics/uschina-coronavirus-disinformation-campaign/index.html. Accessed 29 January 2021.

D’Angelo, Paul, ed. 2010. Doing News Framing Analysis: Empirical and Theoretical Perspectives. Routledge.

Deng, Yong. 2008. China's Struggle for Status: The Realignment of International Relations. Cambridge University Press.

De Lisle, J Jacques. 2010. Soft Power in a Hard Place: China, Taiwan, Cross-Strait Relations and US Policy. Orbis 54(4): 493-524.

Duncombe, Constance. 2017. Twitter and Transformative Diplomacy: Social Media and Iran-US Relations. International Affairs 93(3): 545-562. 
Dworkin, Anthony. 2020. How to Repair Multilateralism After COVID. European Council on Foreign Relations. cfr.eu/article/commentary_how_to_repair_multilateralism_after_covid_19.

Embassy of the People's Republic of China in the Commonwealth of Australia, 2020. Chinese Foreign Ministry Spokesperson's Remarks. http://au.chinaembassy.org/eng/sghdxwfb_1/t1772557.htm.

Entman, Robert M. 1993. Framing: Toward Clarification of a Fractured Paradigm. Journal of Communication 43(4): 51-58.

Erlanger, Steven. 2020.Global Backlash Builds Against China Over Coronavirus. The New York Times. https://www.nytimes.com/2020/05/03/world/europe/backlash-china-coronavirus.html. Accessed on 10 January 2021.

Freeman, D. 2021. The EU and China: Policy Perceptions of Economic Cooperation and Competition. Asia Europe Journal.https://doi.org/10.1007/s10308-021-00609-3

Fruscione, Giorgio. 2021. The pandemic in the Balkans: geopolitics and democracy at stake. The pandemic in the Balkans, 1-125.

Gabuev, Alexander. 2020. The Pandemic Could Tighten China's Grip on Eurasia. Carnegie. https:// carnegie.ru/2020/04/24/pandemic-could-tighten-china-s-grip-on-eurasiapub-81635.

Galbraith, Andrew. 2020. Twitter flags China spokesman's tweet on COVID-19. Reuters. https://www. reuters.com/article/us-twitter-china-factcheck/twitter-flags-china-spokesmans-tweeton-covid19-idUSKBN23506I. Accessed on 18 January 2021.

Garver, John W. 2016. China and Iran: Expanding Cooperation under Conditions of US Domination. In: Toward Well-Oiled Relations? The Nottingham China Policy Institute Series, ed. Horesh N. London: Palgrave Macmillan. https://doi.org/10.1057/9781137539793_12

Geeraerts, Gustaaf. 2019. The EU-China Partnership: Balancing Between Divergence and Convergence. Asia Europe Journal 17(3): 281-294.

Gill, Bates, and Yanzhong Huang. 2006. Sources and Limits of Chinese 'Soft Power.' Survival 48(2): 17-36.

Glaser, Bonnie S., and Melissa E. Murphy. 2009. Soft power with Chinese characteristics. Washington: Center for Strategic and International Studies. http://csis-websiteprod.s3.amazonaws.com/s3fsp ublic/legacy_files/files/media/csis/pubs/090310_chinesesoftpowerchap2.pdf.

Goldstein, Avery. 2020. US-China Rivalry in the Twenty-First Century: Déjà vu and Cold War II. China International Strategy Review 2: 1-15.

Gong, Fanghua, Yong Xiong, Jian Xiao, Li Lin, Xiaodong Liu, Dezhong Wang, and Xiaokun Li. 2020. China's Local Governments are Combating COVID-19 with Unprecedented Responses-From a Wenzhou Governance Perspective. Frontiers of Medicine 14: 220-224.

Hameed, Rashida. 2017. Pakistan and China: Partnership, Prospects and the Course Ahead. Policy Perspectives: THe Journal of the Institute of Policy Studies 14(1): 3-22.

Harnisch, Sebastian. 2011. Introduction. In Role Theory in International Relations: Approaches and Analyses, ed. S. Harnisch, et al., 1-4. London: Routledge.

Harnisch, S., S. Bersick, and J. Gottwald. 2016. China's International Roles Challenging or Supporting International Order? Routledge.

He, K., and S. Walker. 2015. Role Bargaining Strategies for China's Peaceful Rise. The Chinese Journal of International Politics 8(4): 371-388.

Hong, Zhao. 2014. China's Dilemma on Iran: Between Energy Security and a Responsible Rising Power. Journal of Contemporary China 23(87): 408-424

Holsti, Kalevi J. 1970. National Role Conceptions in the Study of Foreign Policy. International Studies Quarterly 14(3): 233-309.

Hornat, Jan. 2012. Is Beijing a Responsible Stakeholder? A Critical Assessment of China's Role in the International System of the 21st Century according to the United States. Archiv Orientalni 80(3): 435-473.

Hsieh, Hsiu-Fang., and Sarah E. Shannon. 2005. Three Approaches to Qualitative Content Analysis. Qualitative Health Research 15(9): 1277-1288.

Jill, Disis., and Jennifer, Hansler. 2020. The United States is 'looking at' Banning TikTok and Other Chinese Social Media Apps, Pompeo Says. CNN. TikTok ban: The US is 'looking at' banning Chinese social media apps, Pompeo says - CNN.

Kiousis, Spiro. 2004. Explicating Media Salience: A Factor Analysis of New York Times Issue Coverage During the 2000 US Presidential Election. Journal of Communication 54(1): 71-87.

Korolev, Alexander, and Vladimir Portyakov. 2018. China-Russia Relations in Times of Crisis: A Neoclassical Realist Explanation. Asian Perspective 42(3): 411-437. 
Kowalski, Bartosz. 2021. China's Mask Diplomacy in Europe: Seeking Foreign Gratitude and Domestic Stability. Journal of Current Chinese Affairs 50(2): 209-226. https://doi.org/10.1177/1868102621 1007147.

Khursheed, Ambreen, et al. 2019. China-Pakistan Economic Corridor: A Harbinger of Economic Prosperity and Regional Peace. Asian Journal of German and European Studies 4(7): 1-15.

Lams, Lutgard. 2016. China: Economic Magnet or Rival? Framing of China in the Dutch-and French-language Elite Press in Belgium and the Netherlands. International Communication Gazette 78(1-2): 137-156.

Li, Cheng, and Ryan McElveen. 2020. Mask diplomacy: How coronavirus upended generations of ChinaJapan antagonism. Brookings. https://www.brookings.edu/blog/order-from-chaos/2020/03/09/ mask-diplomacy-how-coronavirus-upended-generations-of-china-japan-antagonism/.

Lim, Kevjn. 2020. With COVID-19, Iran's Dependence on China Grows. The Washington Institute. https://www.washingtoninstitute.org/policy-analysis/view/with-covid-19-iransdepen dence-on-china-grows.

Liping, Xia. 2001. China: A Responsible Great Power. Journal of Contemporary China 10(26): 17-25.

Lubina, Michal. 2017. Russia and China: A political marriage of convenience-stable and successful. Verlag Barbara Budrich.

Malle, S. 2017. Russia and China in the 21st Century. Moving Towards Cooperative Behaviour. Journal of Eurasian Studies, 8(2): 136-150.

Manheim, Jarol B., and Robert B. Albritton. 1984. Changing National Images: International Public Relations and Media Agenda-Setting. The American Political Science Review 78(3): 641-657.

Medeiros, Evan S. 2019. The Changing Fundamentals of US-China Relations. The Washington Quarterly 42(3): 93-119.

Mehmetcik, Hakan, and Ferit Belder. 2018. China's Role in the Regional and International Management of Korean Conflict: An Arbiter or Catalyst? Third World Quarterly 39(12): 2255-2271.

Melo, Daniella. D. N., and Maria Papageorgiou. 2021. Regionalism on the Run: ASEAN, EU, AU and MERCOSUR Responses Amid the Covid-19 Crisis. Partecipazione E Conflitto, 57-78.

Mello, Patricia Campos. 2020. "Itamaraty abafa diplomacia da máscara, e doações chinesas emperram por logística". Folha de Pernambuco. https://www.folhape.com.br/noticias/itamaratyabafa-diplo macia-da-mascara-e-doacoes-chinesas-emperram-por/144316/. Accessed on 3 February 2021.

Morgenthau, Hans J. 1963. Politics Among Nations. New York: Knopf.

Ministry of Foreign Affairs the PRC. 2020. Qiushi Journal Publishes Article by General Secretary Xi Jinping Entitled "Solidarity and Cooperation Are the Most Powerful Weapons for the International Community to Defeat COVID-19.

Myers, S.L, and Alissa J. Rubin. 2020. Its Coronavirus Cases Dwindling, China Turns Focus Outward. The New York Times. https:/www.nytimes.com/2020/03/18/world/asia/coronavirus-china-aid. html. Accessed on 15 January 2021.

Noesselt, Nele. 2014. China's Contradictory Role(s) in World Politics: Decrypting China's North Korea Strategy. Third World Quarterly 35(7): 1307-1325.

Narlikar, Amrita. 2011. Is India a Responsible Great Power? Third World Quarterly 32(9): 1607-1621.

Patrick, Igor. 2020. "Latin America used to be Positive Toward China. COVID-19 Might Change That". The Diplomat. https://thediplomat.com/2020/04/latin-america-used-to-be-positive-toward-chinacovid-19-might-change-that/. Accessed on 15 January 2021.

Papageorgiou, Maria, and dos Santos Cardoso F. 2021. Chinese Diplomacy, Strategic Partnerships and Global Economic Supremacy. In The New Chinese Dream, eds. F. Spigarelli, and J.R. McIntyre, 51-68. Cham: Palgrave Macmillan. https://doi.org/10.1007/978-3-030-69812-6_4.

Papageorgiou, Maria, and Daniella SN. Melo. 2020. Regional Responses to COVID-19: A Comparative Analysis of EU and ASEAN Policies to Counter the Pandemic. Perspectives on Federalism 10(2): 68-85.

Papageorgiou, Maria, and Alena Vieira. 2021a. A Friend in Need? The Sino-Russian Relationship Under the Coronavirus Crisis in Twitter: A Russian Perspective. East Asia, 38(3): 225-247.

Papageorgiou, Maria, and Alena Vieira. 2021b. Mapping the Literature on China and Russia in IR and Area Studies: A Bibliometric Analysis (1990-2019). Journal of Chinese Political Science 1-27.

Permanent Mission of the PRC to the UN and other International Organizations in Vienna. 2017. President Xi Jinping Speaks with Russian President Vladimir Putin on the Phone. https://www.fmprc. gov.cn/ce/cgvienna/eng/zt/kjxgyq1en/t1770891.htm.

Przystup, James J. 2013. 40th Anniversary: "Fuggetaboutit! Comparative Connections 14(3): 1-16. 
Reuters. 2020. World should learn lessons from China in coronavirus fight - China Daily. https://www. reuters.com/article/health-coronavirus-china-editorial/world-should-learn-lessons-from-china-incoronavirus-fightchina-daily-idUSL4N2BA03Y.

Richardson, Courtney J. 2011. A Responsible Power? China and the UN Peacekeeping Regime. International Peacekeeping 18(3): 286-297.

Rufai, Sohaib R., and Catey Bunce. 2020. World Leaders' Usage Of Twitter in Response to the COVID19 Pandemic: A Content Analysis. Journal of Public Health 42(3): 510-516.

Rühlig, Tim. 2020. Exposing the fragility of EU-China relations. East Asia Forum. https://www.easta siaforum.org/2020/05/23/exposing-the-fragility-of-eu-china-relations/.

Saarela, Anna. 2018. A new era in EU-China relations: more wide-ranging strategic cooperation?. European Parliament. http://www.iberchina.org/files/2018-2/eu_china_relations_new_era_parlamento. pdf.

Sanger, David E., Kirkpatrick David, Wee Sui-Lee and Bennhold Katrin. The New York Times. 2020. https://www.nytimes.com/2020/03/19/us/politics/coronavirus-vaccine-competition.html. Accessed on 15 January 2021.

Santander, Sebastian, and Antonios Vlassis. 2021. The EU in Search of Autonomy in the Era of Chinese Expansionism and COVID-19 Pandemic. Global Policy 12(1): 149-156.

Santis, Esteban Leonardo. 2020. From the Leader's Lips, to the Public's Ears: The State of Exception, Administrative Evil, and the Enemy in President Trump's Rhetoric During COVID-19. Administrative Theory \& Praxis 42(4): 558-570.

Spence, Patric R., et al. 2015. Variability in Twitter Content Across the Stages of a Natural Disaster: Implications for Crisis Communication. Communication Quarterly 63(2): 171-186.

Stuenkel, O. 2020. China's Diplomats Are Going on the Offensive in Brazil. Foreign Policy. https://forei gnpolicy.com/2020/05/15/chinas-diplomats-are-going-on-the-offensive-in-brazi/.

Stryker, Sheldon, and Statham Anne. 1985. Symbolic Interaction and Role Theory. In Handbook of Social Psychology, ed. Gardner Lindzey and Elliot Aronson, 311-378. New York: Random House.

Suzuki, Shogo. 2008. Seeking Legitimate' Great Power Status in Post-Cold War International Society: China's and Japan's Participation in UNPKO. International Relations 22(1): 45-63.

Tass. 2020. Russia closes border with China in Far East over coronavirus. https://tass.com/emergencies/ 1114505. Accessed on 5 January 2021.

Thies, Cameron G. 2009. Role Theory and Foreign Policy. International Studies Association Compendium Project, Foreign Policy Analysis section. http://myweb.uiowa.edu/bhlai/workshop/role.pdf.

Thies, Cameron G. 2013. The United States, Israel, and the Search for International Order: Socializing States. Routledge.

Thomas, Neil. 2020. Great (Power) Expectations: Charting the Evolution of Chinese Foreign Policy. https://macropolo.org/china-great-power-foreign-policy-covid19/.

Terry, G. S., and Makarychev, A. 2021. Performative Diplomacy and Popular Geopolitics: The Case of Russian Anti-COVID Assistance to Italy. Problems of Post-Communism 69(1): 83-91.

Van deVen, Johan. 2020. Fair-Weather Friends: The Impact of the Coronavirus on the Strategic Partnership Between Russia and China. China Brief 20(4): 12-16.

Verma, Raj. 2020. China's 'Mask Diplomacy' to Change the COVID-19 Narrative in Europe. Asia Europe Journal 18: 205-209.

Viola, Lora A. 2020. Systemically Significant States: Tracing the G20's Membership Category as a New Logic of Stratification in the International System. Global Society 34(3): 332-352.

Vreese, Claes, and Hajo Boomgaarden. 2003. Valenced News Frames and Public Support for the EU. Communications 28(4): 361-381.

Walkowicz, J. 2020. China, disinformation and mask diplomacy The Warsaw Institute Review. https:// warsawinstitute.review/interviews/china-disinformation-and-mask-diplomacy/

Wehner, Leslie E., and Cameron G. Thies. 2014. Role Theory, Narratives, and Interpretation: The Domestic Contestation of Roles. International Studies Review 16: 411-436.

Weitz, Richard. 2020. The COVID-19 Pandemic Boosts Sino-Russian Cooperation. China Brief 20(11): 12-17.

Wenting, Xie. 2020. Iranian Ambassador Hails China for Its Help During the Battle Against COVID19. Global Times. https://www.globaltimes.cn/content/1186068.shtml.

Wishnick, E. (2017). In Search of the 'Other' in Asia: Russia-China Relations Revisited. The Pacific Review 30(1): 114-132. 
WHO. 2020a. 2019-nCoV outbreak is an emergency of international concern. https://www.euro.who.int/ en/health-topics/health-emergencies/coronavirus-covid-19/news/news/2020a/01/2019-ncov-outbr eak-is-an-emergency-of-international-concern.

WHO. 2020b. Listings of WHO's response to COVID-19. https://www.who.int/news/item/29-06-2020bcovidtimeline.

Wong, Brian. 2020. China's Mask Diplomacy. The diplomat. https://thediplomat.com/2020/03/chinasmask-diplomacy/. Accessed on 28 January 2021.

Wu, Chengqiu. 2010. Sovereignty, Human Rights, and Responsibility: Changes in China's Response to International Humanitarian Crises. Journal of Chinese Political Science 15(1): 71-97.

Xinhua. 2012. China, Brazil upgrade ties to strategic level. China Daily. https:/www.chinadaily.com.cn/ china/2012wenvisitla/2012-06/22/content_15518325.htm. Accessed on 5 January 2021.

XinhuaNet. 2019. China remains a responsible power around the world, says Chinese FM. http://www. xinhuanet.com/english/2019-10/23/c_138497103.htm. Accessed on 12 January 2021.

XinhuaNet. 2020. Xinhua Headlines:"You are not alone"-countries worldwide offer support, aid to China's fight against coronavirus. http://www.xinhuanet.com/english/2020-02/17/c_138792313.htm. Accessed on 12 January 2021.

Yuan, Nansheng. 2020. Reflections on China-US Relations After the COVID-19 Pandemic. China International Strategy Review 2: 14-23. https://doi.org/10.1007/s42533-020-00049-5

Zaidi, S.M.S., and Adam Saud. 2020. Future of US-China Relations: Conflict, Competition or Cooperation? Asian Social Science 16(7): 1-14.

Zhang, Jian. 2020. China's virus fight projects an image of responsible major power. Global Times. https://www.globaltimes.cn/content/1183345.shtml. Accessed 1 Feb 2021.

Maria Papageorgiou is a PhD Candidate in International Relations at the University of Minho, Portugal, Collaborative Member of the Research Centre in Political Science (CICP) and former visiting scholar at Newcastle University, UK.

Daniella da Silva Nogueira de Melo is a PhD Candidate in International Relations at the University of Minho, Portugal, and Collaborative Member of the Research Centre in Political Science (CICP). 